\title{
Production of gamma-aminobutyric acid by Lactobacillus brevis NCL912 using fed-batch fermentation
}

Haixing $\mathrm{Li}^{1,2}$, Ting $\mathrm{Qiu}^{2}$, Guidong Huang ${ }^{2}$, Yusheng Cao ${ }^{1,2^{*}}$

\begin{abstract}
Background: Gamma-aminobutyric acid is a major inhibitory neurotransmitter in mammalian brains, and has several well-known physiological functions. Lactic acid bacteria possess special physiological activities and are generally regarded as safe. Therefore, using lactic acid bacteria as cell factories for gamma-aminobutyric acid production is a fascinating project and opens up a vast range of prospects for making use of GABA and LAB. We previously screened a high GABA-producer Lactobacillus brevis NCL912 and optimized its fermentation medium composition. The results indicated that the strain showed potential in large-scale fermentation for the production of gamma-aminobutyric acid. To increase the yielding of GABA, further study on the fermentation process is needed before the industrial application in the future. In this article we investigated the impacts of pyridoxal-5'phosphate, $\mathrm{pH}$, temperature and initial glutamate concentration on gamma-aminobutyric acid production by Lactobacillus brevis NCL912 in flask cultures. According to the data obtained in the above, a simple and effective fed-batch fermentation method was developed to highly efficiently convert glutamate to gamma-aminobutyric acid.

Results: Pyridoxal-5'-phosphate did not affect the cell growth and gamma-aminobutyric acid production of $L b$. brevis NCL912. Temperature, $\mathrm{pH}$ and initial glutamate concentration had significant effects on the cell growth and gamma-aminobutyric acid production of $L b$. brevis NCL912. The optimal temperature, $\mathrm{pH}$ and initial glutamate concentration were $30-35^{\circ} \mathrm{C}, 5.0$ and $250-500 \mathrm{mM}$. In the following fed-batch fermentations, temperature, $\mathrm{pH}$ and initial glutamate concentration were fixed as $32^{\circ} \mathrm{C}, 5.0$ and $400 \mathrm{mM} .280 .70 \mathrm{~g}(1.5 \mathrm{~mol})$ and $224.56 \mathrm{~g}(1.2 \mathrm{~mol})$ glutamate were supplemented into the bioreactor at $12 \mathrm{~h}$ and $24 \mathrm{~h}$, respectively. Under the selected fermentation conditions, gamma-aminobutyric acid was rapidly produced at the first $36 \mathrm{~h}$ and almost not produced after then. The gamma-aminobutyric acid concentration reached $1005.81 \pm 47.88 \mathrm{mM}$, and the residual glucose and glutamate were $15.28 \pm 0.51 \mathrm{~g} \mathrm{~L}^{-1}$ and $134.45 \pm 24.22 \mathrm{mM}$ at $48 \mathrm{~h}$.

Conclusions: A simple and effective fed-batch fermentation method was developed for $L b$. brevis NCL912 to produce gamma-aminobutyric acid. The results reveal that $L$ b. brevis NCL912 exhibits a great application potential in large-scale fermentation for the production of gamma-aminobutyric acid.
\end{abstract}

\section{Background}

Gamma-aminobutyric acid (GABA) is a non-protein amino acid that is widely distributed in nature from microorganisms to plants and animals [1]. It acts as the major inhibitory neurotransmitter in the mammalian central nervous system. In addition, GABA has

\footnotetext{
* Correspondence: yyssccc@hotmail.com

'State Key Laboratory of Food Science and Technology, Nanchang

University, Nanchang 330047, PR China

Full list of author information is available at the end of the article
}

hypotensive, tranquilizing and diuretic effects, and can prevent diabetes [2-5]. Also, GABA may improve the concentration of plasma growth hormone and the rate of protein synthesis in the brain [6] and inhibit small airway-derived lung adenocarcinoma [7]. Therefore, GABA has potential as a bioactive component in foods and pharmaceuticals [8]. However, the direction addition of chemical GABA to food is considered unnatural and unsafe [8-10]. So it is necessary to find a natural method to produce and increase GABA in food.
C Biomed Central 
Recent studies have shown that some lactic acid bacteria (LAB) can produce GABA [9,11-19]. LAB possess special physiological activities and are generally regarded as safe (GRAS), and have been extensively utilized in food industries for a long time [20-23]. It is clear that the GABA production by LAB is natural and safe. In addition, the bio-synthetic production of natural GABA produced by LAB for the manufacturing of food can make full use of the health-promoting properties of GABA and LAB themselves. In recent years, the GABA production by using $\mathrm{LAB}$ as bacterial cell factories has therefore been a focus of research [8]. Some fermented products enriched in GABA using GABA-producing LAB as starters such as dairy products $[2,3,24,25]$, black raspberry juice [9], soymilk [26], kimchi [10], and cheese [27] have been developed. The GABA-producing ability varies widely among the strains of $L A B$, and some GABA-producing LAB strains have shown a great promise potential in large-scale fermentation for the production GABA [11,13,15,16,19,28-30].

Since the primary goal of fermentation is the cost-effective and simple production of bio-products, it is important to select a proper process that allows of the highest yielding of the target product. In batch fermentation, substrate should be put in the tank once only. The thing is that the higher initial concentration of fermentation substrate can inhibit the cell growth or waste material resource, and the lower concentration of substrate can not meet the need of high production. Fed-batch culture can make up the weakness and has been widely applied in the production of various bioproducts [31-34]. During fed-batch cultivation, one or more components are supplied to the fermentor while cells and products remain in the tank until the end of operation [31]. A proper initial substrate concentration not inhibiting cell growth can be selected in a fed-batch fermentation, and the limitation component can be added with feeding in the fermentation course. It may help to obtain a high yield and productivity. We previously screened a high GABA-producing Lb. brevis NCL912 [11] and the GABA concentration reached $345.83 \mathrm{mM}$ in the optimized fermentation medium [35]. To further increase the yielding of GABA, the effects of pyridoxal-5'-phosphate (PLP), $\mathrm{pH}$, temperature and initial glutamate concentration on the GABA production by Lactobacillus brevis NCL912 were firstly determined using flask fermentation in this work. Then a simple process for efficient production of GABA by fed-batch fermentation using $L b$. brevis NCL912 was developed.

\section{Results and discussion}

\section{Effect of PLP on GABA production and bacterial growth}

Glutamic acid decarboxylase (GAD, EC 4.1.1.15) catalyzes the irreversible $\alpha$-decaboxylation of glutamate to produce GABA. GAD uses PLP as coenzyme. Therefore, from the theoretical point of view, an addition of PLP to medium may be a workable method to increase GAD activity to enhance synthetic capacity of GABA. Previous studies had shown that the addition of PLP to medium could effectively increase the GABA production of LAB $[15,19]$. In our present study, however, the addition of PLP neither affected the cell growth (Figure 1A) nor increased GABA content (Figure 1B) in the fermentation. The possible reason was that NCL912 cells could synthesize sufficient PLP for themselves.

\section{Effect of temperature on GABA synthesis and bacterial growth}

Figure 2 shows that the considerable variation in the yields of both bacterial growth and GABA production under different fermentation temperatures. The bacterial growth increased with the increase of temperature and peaked at $35^{\circ} \mathrm{C}$, then decreased with the increase of temperature. For GABA production, a trend similar to the bacterial growth was observed. It was clear that high cell density was required for effective synthesis of GABA. On the other hand, GABA concentration at $30^{\circ} \mathrm{C}$ was almost the same to that at $35^{\circ} \mathrm{C}$ but biomass at $30^{\circ} \mathrm{C}$ was less than that at $35^{\circ} \mathrm{C}$. In addition, NCL912 could not produce GABA at $45^{\circ} \mathrm{C}$ while the strain could grow under this temperature. These data indicated that appropriate temperature was beneficial to produce GABA, and excessively high temperature was unfavorable to the GABA production. The above results indicated that high efficient conversion glutamate to GABA needed not only high cell density but also appropriate temperature. By comprehensive consideration of the above data, $32^{\circ} \mathrm{C}$ was selected for the following tests.

\section{Effect of pH on GABA synthesis and bacterial growth}

It was reported that the GABA biosynthesis in LAB was strictly $\mathrm{pH}$ regulated $[15,19,36]$. To investigate the effect of different $\mathrm{pH}$ levels on the production of biomass and GABA of NCL912 in the course of fermentation, the initial pHs of the media were adjusted to $3,4,5$ and 6 , respectively. During the fermentation process, the $\mathrm{pHs}$ were adjusted to corresponding initial values immediately after sampling, respectively. As shown in Figure 3, pH has a significant effect on the production of biomass and GABA. The strain could hardly grow at pH3.0 and almost no GABA produced. A highest yield of GABA was obtained at pH5.0 in the fermentation course even if the biomass was less than that of pH6.0 after $24 \mathrm{~h}$. The optimal $\mathrm{pH}$ value for the GABA production was 5.0 that accorded with the previous reports about the optimal $\mathrm{pH}$ values for maintaining the activity of LAB GADs were in the range of 4.0 to 5.0 [14,37-39]. The higher or lower $\mathrm{pH}$ may lead to the partial loss of the GAD activity.

$\mathrm{pH} 5.0$ was also the optimal $\mathrm{pH}$ for the cell growth, though the biomass decreased drastically after $24 \mathrm{~h}$. 

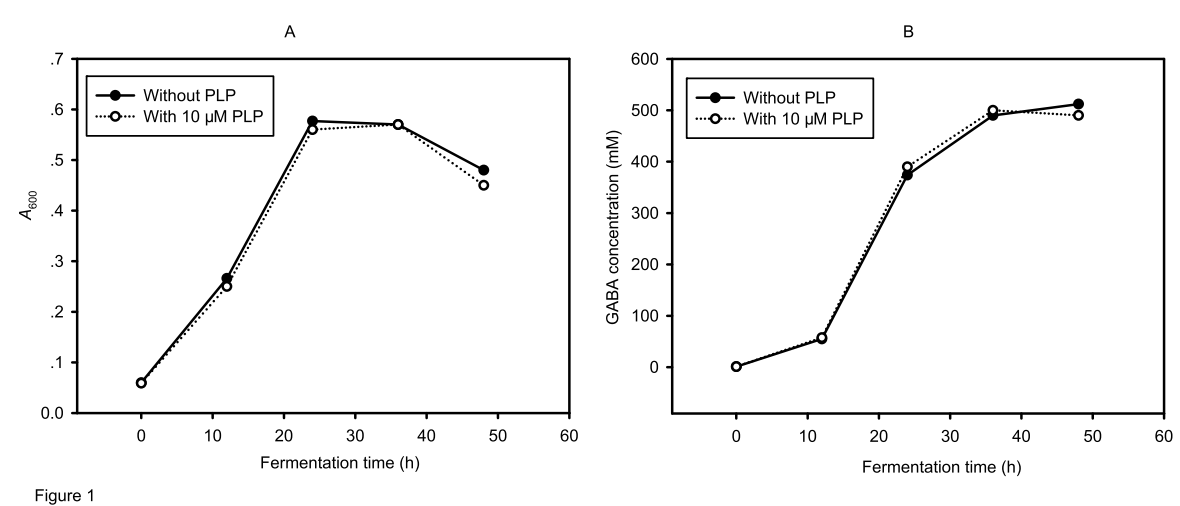

Figure 1 Influence of PLP on the cell growth (A) and GABA production (B) of Lb. brevis NCL912.

However, the biomass kept increasing during the fermentation course when $\mathrm{pH}$ values were maintained at 4.0 or 6.0. It might be the combined inhibitory effect of high concentration of GABA and $\mathrm{H}_{2} \mathrm{SO}_{4}$. For pH5.0, more GABA was produced than $\mathrm{pH} 4.0$ and 6.0. The decarboxylation of glutamate to GABA catalyzed by GAD takes the following general form $[1,8]$ :

$$
\text { L-glutamate }+\mathrm{H}^{+} \stackrel{\mathrm{GAD}}{\longrightarrow} \mathrm{GABA}+\mathrm{CO}_{2}
$$

Decarboxylation of glutamate occurred in LAB results in the stoichiometric release of the end product GABA and the consumption of a proton. The net effect of this reaction is to increase the alkalinity of the cytoplasm and environment. For pH5.0, more $\mathrm{H}_{2} \mathrm{SO}_{4}$ was therefore supplemented into the fermentation broth in order to offset $\mathrm{pH}$ increase arising from the decarboxylation.

\section{Effect of initial glutamate concentration on GABA production and bacterial growth}

As shown in Figure 4A, a moderate addition of glutamate to the medium resulted in an increase in biomass.
LAB can metabolize sugars to produce large amount of low weight molecule organic acids, resulting in an acidic environment that was hard for bacteria growth. Some LAB can employ GAD system for maintaining neutral cytoplasmic $\mathrm{pH}$ when the external $\mathrm{pH}$ drops because the decarboxylation of glutamate within the LAB cell consumes an intracellular proton. In Figure $4 \mathrm{C}$, the $\mathrm{pH}$ value of the culture without glutamate decreased to 3.4 after $24 \mathrm{~h}$ of fermentation. $\mathrm{pH}$ values of the cultures supplemented with glutamate, however, are generally above 5.0. It implied that GAD system of $L b$. brevis NCL912 acted under low $\mathrm{pH}$ and resulted in an increase of $\mathrm{pH}$ in medium with glutamate, and protected cell survival from acidic condition. The role of GAD conferring acid resistance to microbial cells was further verified in the present study. On the other hand, the cell growth and biomass decreased with the increase of glutamate concentration at the given levels $(0.25,0.5,0.75$ and $1.0 \mathrm{M})$. It was apparent that extra high concentration of glutamate was harmful to the strain growth. An addition of 0.25-0.5 $\mathrm{M}$ of glutamate was suitable for the strain NCL912 growth and production of GABA.
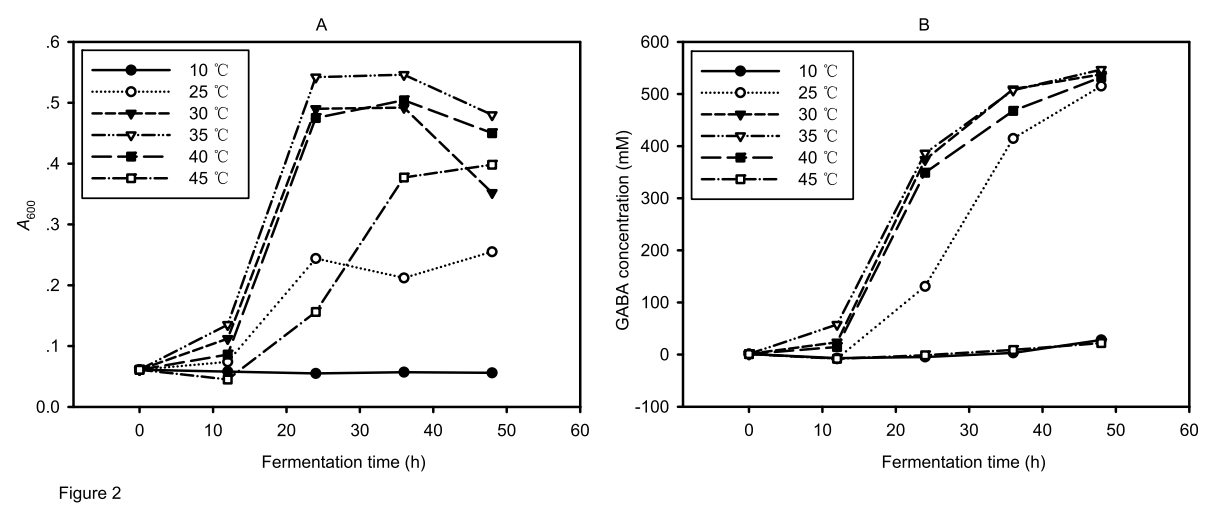

Figure 2 Influence of fermentation temperature on the cell growth (A) and GABA production (B) of Lb. brevis NCL912. 

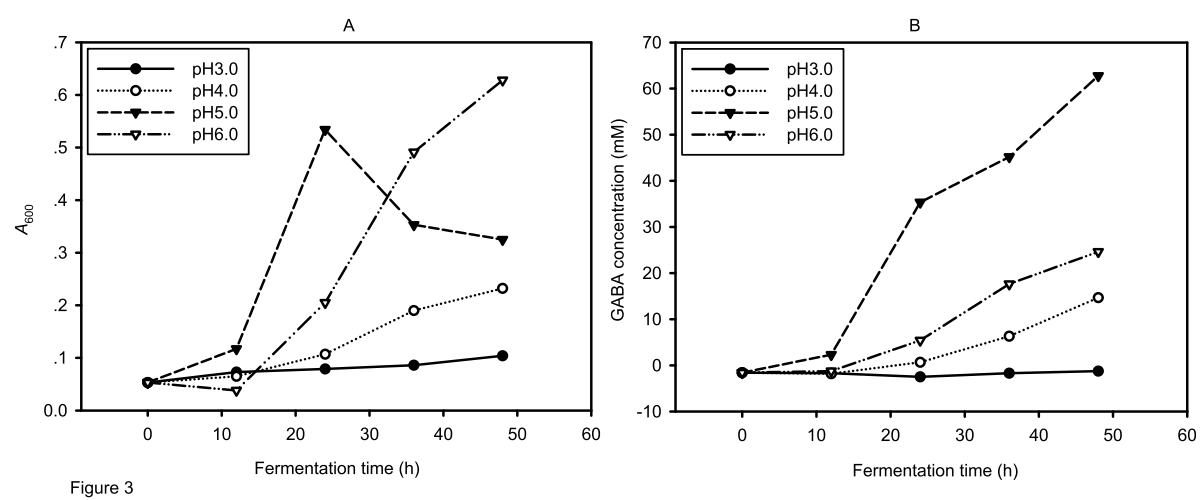

Figure 3 Influence of $\mathrm{pH}$ on the cell growth (A) and GABA production (B) of Lb. brevis NCL912.

\section{Fed-batch production of GABA with $\mathrm{pH}$ control}

In the fed-batch process, the initial concentration of glutamate in medium was $400 \mathrm{mM}$, for the cell growth was strongly inhibited when glutamate exceeded $500 \mathrm{mM}$. The time courses of GABA production, residual glutamate, DCW, and residual glucose were tested (Figure 5). The cell growth occurred immediately after inoculation and biomass rapidly increased at the first $12 \mathrm{~h}$. And then the biomass dramatically decreased due to the combined inhibitory effect of high concentration of GABA, glutamate and $\mathrm{H}_{2} \mathrm{SO}_{4}$. The concentrations of GABA and glutamate were $381.6 \mathrm{mM}$ and $484.6 \mathrm{mM}$ at $12 \mathrm{~h}$, respectively. In addition, about $100 \mathrm{ml}$ of $10 \mathrm{~N}$ $\mathrm{H}_{2} \mathrm{SO}_{4}$ was supplemented into the fermentor in order to offset $\mathrm{pH}$ increase arising from the glutamate addition and the decarboxylation. Such harsh conditions were certainly detrimental to the cells and therefore resulted in a sharp decline in biomass after $12 \mathrm{~h}$. The cell growth was almost completely inhibited after $36 \mathrm{~h}$. Without question, compared to feeding strategies maintaining low level glutamate, the current utilized feeding strategy strongly inhibited the cell growth. This feeding strategy, however, was simple and energy-saving. The most important was that the current fermentation method still exhibited powerful capacity of synthesis of GABA (reaching $1095.63 \pm 61.03 \mathrm{mM}$ at the end of the fermentations). The biosynthetic kinetics indicate that the GABA concentration increased rapidly with the fermentation time from 0-36 h, increased slowly from 36-60 h, and kept constant after $60 \mathrm{~h}$. The GABA concentrations at 36,48 and $60 \mathrm{~h}$ were $931.50 \pm 29.65,1005.81 \pm 47.88$ and $1075.05 \pm 82.72 \mathrm{mM}$, respectively, which were obviously higher than that $(345.83 \mathrm{mM})$ [35] before the optimization. Based on a comprehensive consideration of the GABA concentration, energy conservation and fermentation period, $48 \mathrm{~h}$ of fermentation was recommended in the future practical production. The volume of the fermentation broth was increased to about $3.75 \mathrm{~L}$ due to the inoculation and feed. Residual glutamate and glucose were $134.45 \pm 24.22 \mathrm{mM}$ and15.28 $\pm 0.51 \mathrm{~g} \mathrm{~L}^{-1}$ at $48 \mathrm{~h}$. Total $738.24 \mathrm{~g}$ glutamate (plus the glutamate in the seed medium) was added into the fermentation medium, in which the converted glutamate was 705.81 $\pm 33.60 \mathrm{~g}$ according to the generated GABA mol number, and the residual glutamate was $94.35 \pm 17.00 \mathrm{~g}$. This good balance of glutamate added, converted and
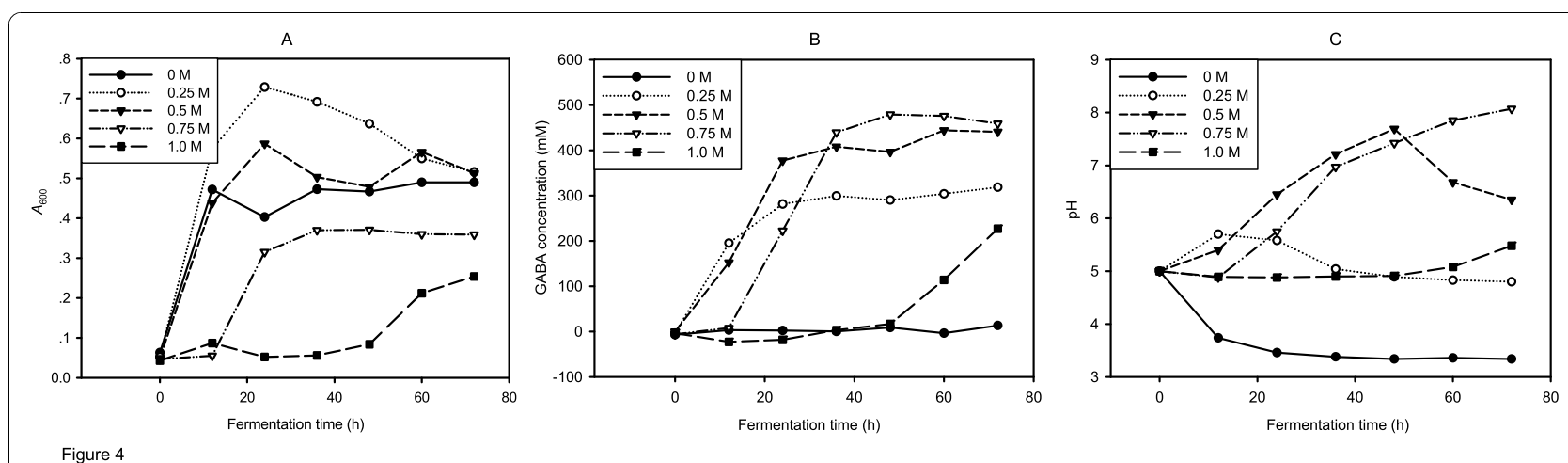

Figure 4 Effect of initial sodium L-glutamate concentration on the growth (A) and GABA production (B) of $L b$. brevis NCL912; pH profile $(C)$ of fermentation broths fermented by $L b$. brevis NCL912 with different initial sodium L-glutamate concentrations. 

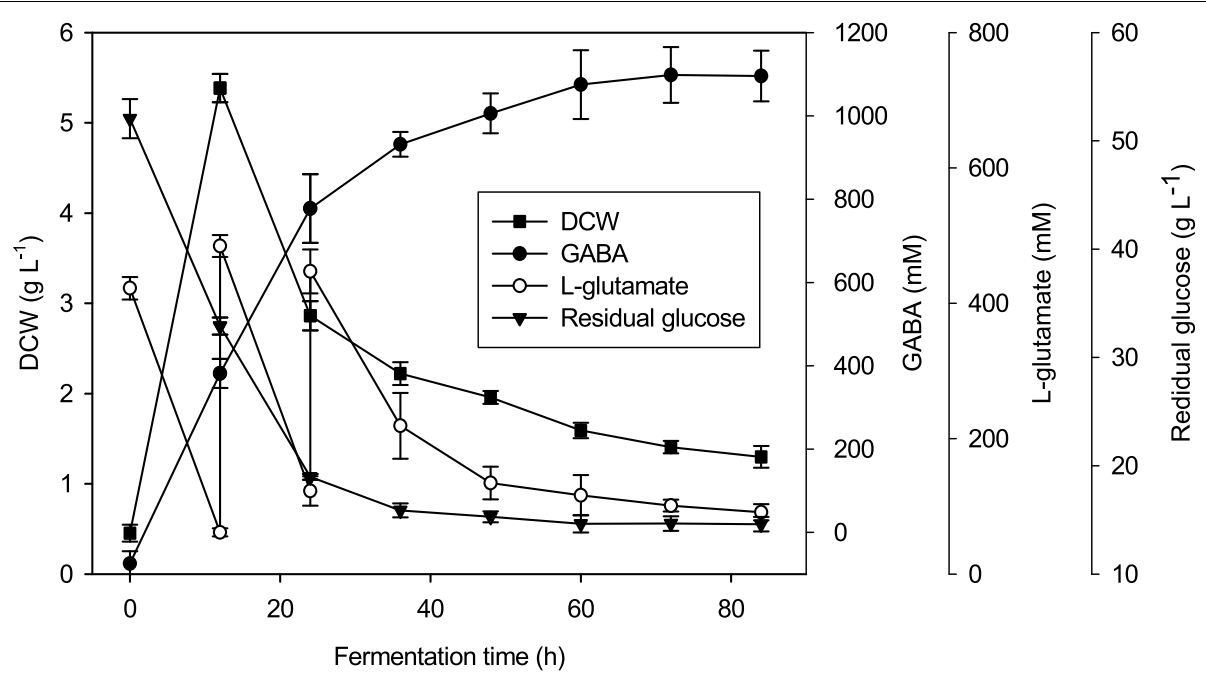

Figure 5 Time courses of GABA production, residual glutamate, dry cell weight, and residual glucose in fed-batch fermentation. Data are the means of three independent experiments \pm standard deviations $(n=3)$ analyzed in duplicate.

residual showed that the added glutamate did not participate in other metabolisms. Complete conversion of substrates was beneficial to save material and purify the end product from culture broth. In further practical applications, an addition of $112.28 \mathrm{~g}$ glutamate at $24 \mathrm{~h}$, and $35 \mathrm{~g} \mathrm{~L}^{-1}$ of glucose in the medium are suggested.

\section{Conclusions}

In this study we investigated the effects of PLP, temperature, $\mathrm{pH}$ and initial glutamate concentration on the GABA production and bacterial growth of Lb. brevis NCL912. PLP did not affect the bacterial growth and the GABA production. In contrast, temperature, $\mathrm{pH}$ and initial glutamate concentration had a significant effect on the cell growth and the GABA production, and the conditions were optimized. Then a simple and effective fed-batch fermentation method was developed as follows. The fermentation medium [35] was inoculated with $10 \%(\mathrm{v} / \mathrm{v})$ seed culture grown to early exponential phase at $32^{\circ} \mathrm{C}$. The fedbatch fermentation was carried out under the following conditions: temperature $32^{\circ} \mathrm{C}$, agitation speed $100 \mathrm{rpm}$, $\mathrm{pH} 5.0$, and fermentation time $48 \mathrm{~h}$. $280.70 \mathrm{~g}$ and $224.56 \mathrm{~g}$ of glutamate were fed into the bioreactor at $12 \mathrm{~h}$ and $24 \mathrm{~h}$, respectively. The GABA concentration reached 1005.81 \pm $47.88 \mathrm{mM}$ at $48 \mathrm{~h}$. To ensure a complete utilization of glutamate and glucose, $400 \mathrm{mM}$ of glutamate and $35 \mathrm{~g} \mathrm{~L}^{-1}$ of glucose in the initial medium, and the addition of $280.70 \mathrm{~g}$ glutamate at $12 \mathrm{~h}$ and $112.28 \mathrm{~g}$ glutamate at $24 \mathrm{~h}$ into the bioreactor, are suggested.

\section{Methods}

Strain, medium and cultivation

GABA-producing $L b$. brevis NCL912 was isolated by our laboratory from paocai, a Chinese traditional fermented vegetable [11]. In a previous study, we optimized the fermentation medium for production of GABA by $L b$. brevis NCL912, and this medium was theoretically composed of $\left(\mathrm{g} \mathrm{L}^{-1}\right)$ [35]: glucose, 55.25; soya peptone, 30.25; $\mathrm{MnSO}_{4} \cdot 4 \mathrm{H}_{2} \mathrm{O}, 0.0061$; and Tween- $801.38 \mathrm{~mL} \mathrm{~L}^{-1}$. To facilitate the calculation and preparation of the medium in practice, we adjusted the medium components to $\left(\mathrm{g} \mathrm{L}^{-1}\right)$ : glucose, 50; soya peptone, $25 ; \mathrm{MnSO}_{4} \cdot 4 \mathrm{H}_{2} \mathrm{O}, 0.01$; and Tween $80,2 \mathrm{~mL} \mathrm{~L}^{-1}$. Unless otherwise emphasized, the initial sodium L-glutamate concentration in the medium was $500 \mathrm{mM}$. The seed medium was composed of $\left(\mathrm{g} \mathrm{L}^{-1}\right)$ : glucose, 50; soya peptone, $25 ; \mathrm{MnSO}_{4} \cdot 4 \mathrm{H}_{2} \mathrm{O}, 0.01$; L-glutamate, $150 \mathrm{mM}$; and Tween $80,2 \mathrm{~mL} \mathrm{~L}^{-1}$. Nitrogen sources, glutamate and the other compositions were autoclaved separately at $121^{\circ} \mathrm{C}$ for 20 min and mixed together prior inoculation. $L b$. brevis NCL912 was cultured in the seed medium at $32^{\circ} \mathrm{C}$ for $10 \mathrm{~h}$ till the absorbance value at 600 $\mathrm{nm}\left(A_{600}\right)$ between 4.0 and 6.0 and then used for seed culture inoculation. Culture condition optimization was conducted in 250-mL Erlenmeyer flasks that contained $100 \mathrm{~mL}$ of the medium. The flasks were inoculated with $10 \%(\mathrm{v} / \mathrm{v})$ seed culture grown to early exponential phase, and incubated under static conditions in an incubator. The fed-batch fermentation was carried out in a 5-L fermentor (Labo-controller MDL-8C; B. E. Marubishi, Tokyo, Japan) under following conditions: medium volume $3 \mathrm{~L}$, inoculum size $10 \%(\mathrm{v} / \mathrm{v})$, temperature $32^{\circ} \mathrm{C}$, $\mathrm{pH}$ 5.0, agitation speed $100 \mathrm{rpm}$, and fermentation time $84 \mathrm{~h}$. The $\mathrm{pH}$ was kept constant at 5.0 with addition of $10 \mathrm{~N} \mathrm{H}_{2} \mathrm{SO}_{4}$. $280.70 \mathrm{~g}$ and $224.56 \mathrm{~g}$ glutamate were supplemented into the bioreactor at $12 \mathrm{~h}$ and $24 \mathrm{~h}$, respectively. Each flask fermentation was performed in two replicates and the fed-batch fermentation was performed in three replicates. 


\section{Analytic procedures}

Glutamate and GABA concentrations in the culture broths were determined by pre-staining paper chromatography [40]. Cell growth was monitored by measuring $A_{600}$ on a TU-1901 UV-vis spectrophotometer (Beijing Purkinje General Instrument, China). Dry cell weight (DCW) was calculated by a consistent calibration curve of DCW versus $A_{600}$. Glucose concentration was determined by 3, 5-dinitrosalicylic acid method [41]. Each sample was analyzed in duplicate and the mean values were calculated.

\section{Author details}

'State Key Laboratory of Food Science and Technology, Nanchang University, Nanchang 330047, PR China. ${ }^{2}$ Sino-German Joint Research Institute, Nanchang University, Nanchang 330047, PR China.

\section{Authors' contributions}

The initiative for this work came from YC. YC and HL designed the experiments; $\mathrm{HL}$ and TQ carried out the experimental work; $\mathrm{HL}$ and $\mathrm{GH}$ analyzed data; YC and HL drafted the manuscript. All authors read and approved the final manuscript.

\section{Competing interests}

The authors declare that they have no competing interests.

Received: 20 July 2010 Accepted: 12 November 2010 Published: 12 November 2010

\section{References}

1. Ueno H: Enzymatic and structural aspects on glutamate decarboxylase. $J$ Mol Catal B: Enzym 2000, 10:67-79.

2. Hayakawa K, Kimura M, Kasaha K, Matsumoto K, Sansawa H, Yamori Y: Effect of a gamma-aminobutyric acid-enriched dairy product on the blood pressure of spontaneously hypertensive and normotensive WistarKyoto rats. Br J Nutr 2004, 92:411-417.

3. Inoue K, Shirai T, Ochiai H, Kasao M, Hayakawa K, Kimura M, Sansawa H: Blood-pressure-lowering effect of a novel fermented milk containing gamma-aminobutyric acid (GABA) in mild hypertensives. Eur J Clin Nutr 57(3):490-495, 003.

4. Jakobs C, Jaeken J, Gibson KM: Inherited disorders of GABA metabolism. J Inherit Metab Dis 1993, 16:704-715.

5. Wong CG, Bottiglieri T, Snead OC: GABA, gamma-hydroxybutyric acid, and neurological disease. Ann Neurol 2003, 54:S3-12.

6. Tujioka K, Ohsumi M, Horie K, Kim M, Hayase K, Yokogoshi H: Dietary gamma-Aminobutyric Acid Affects the Brain Protein Synthesis Rate in Ovariectomized Female Rats. J Nutr Vitaminol 2009, 55:75-80.

7. Schuller HM, Al-Wadei HAN, Majidi M: Gamma-aminobutyric acid, a potential tumor suppressor for small airway-derived lung adenocarcinoma. Carcinogenesis 2008, 29:1979-1985.

8. Li H, Cao Y: Lactic acid bacterial cell factories for gamma-aminobutyric acid. Amino Acids

9. Kim JY, Lee MY, Ji GE, Lee YS, Hwang KT: Production of gammaaminobutyric acid in black raspberry juice during fermentation by Lactobacillus brevis GABA100. Int J Food Microbiol 2009, 130:12-16.

10. Seok JH, Park KB, Kim YH, Bae MO, Lee MK, Oh SH: Production and characterization of kimchi with enhanced levels of gamma-aminobutyric acid. Food Sci Biotechnol 2008, 17:940-946.

11. Li H, Cao Y, Gao D, Xu H: A high $\gamma$-aminobutyric acid-producing ability Lactobacillus brevis isolated from Chinese traditional paocai. Ann Microbiol 2008, 58:649-653.

12. Siragusa S, De Angelis M, Di Cagno R, Rizzello CG, Coda R, Gobbetti M: Synthesis of $\mathrm{Y}$-aminobutyric acid by lactic acid bacteria isolated from a variety of Italian cheeses. Appl Environ Microbiol 2007, 73:7283-7290.

13. Yokoyama S, Hiramatsu J, Hayakawa K: Production of gammaaminobutyric acid from alcohol distillery lees by Lactobacillus brevis IFO12005. J Biosci Bioeng 2002, 93:95-97.
14. Nomura M, Nakajima I, Fujita Y, Kobayashi M, Kimoto H, Suzuki I, Aso H: Lactococcus lactis contains only one glutamate decarboxylase gene. Microbiology 1999, 145:1375-1380.

15. Komatsuzaki N, Shima J, Kawamoto S, Momose H, Kimura T: Production of gamma-aminobutyric acid (GABA) by Lactobacillus paracasei isolated from traditional fermented foods. Food Microbiol 2005, 22:497-504.

16. Cho YR, Chang JY, Chang HC: Production of gamma-aminobutyric acid (GABA) by Lactobacillus buchneri isolated from kimchi and its neuroprotective effect on neuronal cells. J Microbiol Biotechnol 2007 17:104-109.

17. Park KB, Oh SH: Isolation and characterization of Lactobacillus buchneri strains with high gamma-aminobutyric acid producing capacity from naturally aged cheese. Food Sci Biotechnol 2006, 15:86-90.

18. Sun TS, Zhao SP, Wang HK, Cai CK, Chen YF, Zhang HP: ACE-inhibitory activity and gamma-aminobutyric acid content of fermented skim milk by Lactobacillus helveticus isolated from Xinjiang koumiss in China. Eur Food Res Technol 2009, 228:607-612.

19. Yang SY, Lu FX, Lu ZX, Bie XM, Jiao Y, Sun LJ, Yu B: Production of gammaaminobutyric acid by Streptococcus salivarius subsp thermophilus Y2 under submerged fermentation. Amino Acids 2008, 34:473-478.

20. Karahan AG, Kilic GB, Kart A, Aloglu HS, Oner Z, Aydemir S, Erkus O, Harsa S: Genotypic identification of some lactic acid bacteria by amplified fragment length polymorphism analysis and investigation of their potential usage as starter culture combinations in Beyaz cheese manufacture. J Dairy Sci 2010, 93:1-11.

21. Lee JY, Kim CJ, Kunz B: Identification of lactic acid bacteria isolated from kimchi and studies on their suitability for application of as starter culture in the production fermented sausages. Meat Sci 2006, 72:437-445.

22. Leroy F, De Vuyst L: Lactic acid bacteria as functional starter cultures for the food fermentation industry. Trends Food Sci Technol 2004, 15:67-78.

23. Yan PM, Xue WT, Tan SS, Zhang H, Chang XH: Effect of inoculating lactic acid bacteria starter cultures on the nitrite concentration of fermenting Chinese paocai. Food Control 2008, 19:50-55.

24. Park KB, Oh SH: Production of yogurt with enhanced levels of gammaaminobutyric acid and valuable nutrients using lactic acid bacteria and germinated soybean extract. Bioresour Technol 2007, 98:1675-1679.

25. Skeie S, Lindberg C, Narvhus J: Development of amino acids and organic acids in Norvegia, influence of milk treatment and adjunct Lactobacillus. Int Dairy J 2001, 11:399-411.

26. Tsai JS, Lin YS, Pan BS, Chen TJ: Antihypertensive peptides and gammaaminobutyric acid from prozyme 6 facilitated lactic acid bacteria fermentation of soymilk. Process Biochem 2006, 41:1282-1288.

27. Nomura M, Kimoto H, Someya Y, Furukawa S, Suzuki I: Production of gamma-aminobutyric acid by cheese starters during cheese ripening. $J$ Dairy Sci 1998, 81:1486-1491.

28. Choi SI, Lee JW, Park SM, Lee MY, Ji GE, Park MS, Heo TR: Improvement of gamma-aminobutyric acid (GABA) production using cell entrapment of Lactobacillus brevis GABA 057. J Microbiol Biotechnol 2006, 16:562-568.

29. Huang J, Le-He M, Wu H, Lin DQ: Biosynthesis of gamma-aminobutyric acid (GABA) using immobilized whole cells of Lactobacillus brevis. World J Microbiol Biotechnol 2007, 23:865-871.

30. Kim SH, Shin BH, Kim YH, Nam SW, Jeon SJ: Cloning and expression of a full-length glutamate decarboxylase gene from Lactobacillus brevis $\mathrm{BH} 2$. Biotechnol Bioprocess Eng 2007, 12:707-712.

31. Krause M, Ukkonen K, Haataja T, Ruottinen M, Glumoff T, Neubauer A, Neubauer P, Vasala A: A novel fed-batch based cultivation method provides high cell-density and improves yield of soluble recombinant proteins in shaken cultures. Microb Cell Fact 2010, 9:11.

32. Ihssen J, Kowarik M, Dilettoso S, Tanner C, Wacker M, Thöny-Meyer L: Production of glycoprotein vaccines in Escherichia coli. Microb Cell Fact 2010, 9:61.

33. Glazyrina J, Materne EM, Dreher T, Storm D, Junne S, Adams T, Greller G, Neubauer P: High cell density cultivation and recombinant protein production with Escherichia coli in a rocking- motion- type bioreactor. Microb Cell Fact 2010, 9:42.

34. Hahn-Hagerdal B, Karhumaa K, Larsson CU, Gorwa-Grauslund M, Gorgens J, van Zyl WH: Role of cultivation media in the development of yeast strains for large scale industrial use. Microb Cell Fact 2005, 4:31.

35. Li H, Qiu T, Gao D, Cao Y: Medium optimization for production of gamma-aminobutyric acid by Lactobacillus brevis NCL912. Amino Acids 2010, 38:1439-1445. 
36. Sanders JW, Leenhouts K, Burghoorn J, Brands JR, Venema G, Kok J: A chloride-inducible acid resistance mechanism in Lactococcus lactis and its regulation. Mol Microbiol 1998, 27:299-310.

37. Komatsuzaki N, Nakamura T, Kimura T, Shima J: Characterization of glutamate decarboxylase from a high gamma-aminobutyric acid (GABA)producer, Lactobacillus paracasei. Biosci Biotechnol Biochem 2008, 72:278-285.

38. Huang J, Mei LH, Sheng Q, Yao SJ, Lin DQ: Purification and characterization of glutamate decarboxylase of Lactobacillus brevis CGMCC 1306 isolated from fresh milk. Chin J Chem Eng 2007, 15:157-161.

39. Ueno $Y$, Hayakawa $K$, Takahashi $S$, Oda K: Purification and characterization of glutamate decarboxylase from Lactobacillus brevis IFO 12005. Biosci Biotechnol Biochem 1997, 61:1168-1171.

40. Li H, Qiu T, Cao Y, Yang J, Huang Z: Pre-staining paper chromatography method for quantification of gamma-aminobutyric acid. J chromatogr $A$ 2009, 1216:5057-5060.

41. Miller GL: Use of dinitrosalicylic acid reagent for determination of reducing sugar. Anal Chem 1959, 31:426-428.

doi:10.1186/1475-2859-9-85

Cite this article as: Li et al:: Production of gamma-aminobutyric acid by Lactobacillus brevis NCL912 using fed-batch fermentation. Microbial Cell Factories 2010 9:85.

\section{Submit your next manuscript to BioMed Central and take full advantage of:}

- Convenient online submission

- Thorough peer review

- No space constraints or color figure charges

- Immediate publication on acceptance

- Inclusion in PubMed, CAS, Scopus and Google Scholar

- Research which is freely available for redistribution

Submit your manuscript at www.biomedcentral.com/submit 